\title{
PENERAPAN MODEL PEMBELAJARAN KOOPERATIF \\ TIPE STUDENT TEAMS ACHIEVEMENT DIVISION (STAD) MELALUI \\ LESSON STUDY UNTUK MENINGKATKAN KEAKTIFAN SISWA \\ PADA MATA PELAJARAN RENCANA ANGGARAN BIAYA KELAS X TEKNIK GAMBAR BANGUNAN SMK NEGERI 2 SUKOHARJO TAHUN PELAJARAN 2016/2017
}

Oleh:

1. Fajar Ayu Prabandini

2. Sri Sumarni, S.T., M.T.

Abdul Haris Setiawan, S.Pd., M.Pd.

Email:parkhyurin20@gmail.co.id

\begin{abstract}
ABSTRAK
Tujuan penelitian adalah untuk mengetahui peningkatan keaktifan siswa dan hasil belajar siswa dalam pelajaran Rencana Anggaran Biaya pada siswa kelas X A Teknik Gambar Bangunan SMK Negeri 2 Sukoharjo menggunakan model pembelajaran kooperatif tipe Student Teams Achievement Division (STAD) melalui Lesson study.

Penelitian ini merupakan penelitian tindakan kelas. Penelitian ini dilaksanakan dalam III siklus, setiap siklus meliputi tahap perencanaan (plan), tahap pelaksanaan (do), tahap observasi, dan tahap refleksi (see). Subyek penelitian adalah siswa kelas X A Teknik Gambar Bangunan SMK N 2 Sukoharjo tahun ajaran 2016/2017. Data diperoleh melalui observasi ranah afektif, psikomotorik, dan keaktifan siswa, wawancara, tes dan dokumentasi. Triangulasi data digunakan untuk menjaga validasi data, sedangkan untuk analisa data menggunakan teknik analisis interaktif kualitatif.

Kesimpulan penelitian adalah odel pembelajaran kooperatif tipe Student Teams Achievement Division (STAD) melalui Lesson study dapat meningkatan keaktifan siswa dan hasil belajar siswa dalam pelajaran Rencana Anggaran Biaya pada siswa kelas X A Teknik Gambar Bangunan SMK Negeri 2 Sukoharjo.
\end{abstract}

Kata kunci: pembelajaran kooperatif tipe Student Teams Achievement Division (STAD), Lesson study, keaktifan.

1.Pendidikan Teknik Bangunan FKIP UNS

2. Pengajar Pendidikan Teknik Bangunan FKIP UNS

Pengajar Pendidikan Teknik Bangunan FKIP UNS 


\begin{abstract}
The purposes of the research are: To determine the improvement of student activeness and student learning outcomes in real estimate of cost subject in tenth grade of class A Architecture Engineering SMK N 2 Sukoharjo using cooperative learning model student Teams Achievement Division (STAD) through lesson study.

This research is a classroom action research. This research is conducted in three cycles, there are several stages includes of planning stage each cycle, implementation, observation, and reflection. The subjects of the research were the students tenth grade of class A Architecture Engineering SMK N 2 Sukoharjo academic year 2016/2017. The Data was obtained through observation of the affective, psychomotor, and student activeness, interviews, tests and documentation. Triangulation of data used to maintain data validation, while for data analysis using interactive qualiative analysis techniques.

The conclusions of the research are Student Teams Achievement Division (STAD) cooperative learning model through Lesson study can increase student activeness and student learning outcomes in real estimate of cost subject in tenth grade of class A students architecture engineering SMK N 2 Sukoharjo.
\end{abstract}

Keywords: cooperative learning Student Teams Achievement Division (STAD), Lesson study, activeness

PENDAHULUAN

Menurut Alferd Alder yag dikutip dalam Warsono \& Hariyanto (2012: 4) menyatakan "All genuine learning is active, not passive. It is a process of discoverybin which the studentnin the main agent, not the teacher." Alferd Alder menjelaskan belajar yang sukses adalah belajar yang memunculkan keaktifan bukan pasif. Keaktifan adalah sebuah proses yang dimulai dan didominasi oleh siswa, bukan guru.
Berdasarkan pengamatan yang dilakukan, suasana pembelajaran pada mata pelajaran Rencana Anggaran Biaya Kelas X A Teknik Gambar Bangunan SMK Negeri 2 Sukoharjo tahun ajaran 2016/2017 masih menggunakan cara klasikal. Dengan menggunakan cara belajar klasikal akibatnya siswa merasa jenuh, sebagian siswa ada yang mengobrol dengan temannya, ada yang mengantuk dan saat pembelajaran berlangsung siswa cenderung tidak aktif sehingga aktifitas 
belajar siswa kurang. Sebanyak $83,87 \%$ satu upaya pembinaan untuk siswa mengatakan bahwa selama meningkatkan proses pembelajaran pembelajaran berlangsung mereka yang dilakukan oleh sekelompok guru kurang aktif bertanya dan menjawab secara kolaboratif dan berpertanyaan yang diberikan guru, kesinambungan dalam merencana-kan, sehingga pembelajaran kurnag aktif. melaksanakan, mengobservasi, dan Dalam mata pelajaran Rencana melaporkan hasil pembelajaran. Anggaran Biaya diharapkan siswa Berkaitan dengan kurang aktifnya benar-benar aktif sehingga akan siswa kelas X A dalam pembelajaran berdampak pemahaman siswa tentang Rencana Anggaran Biaya, maka perlu apa yang dipelajari, sehingga diupayakan suatu bentuk pembelajaran dibutuhkan metode pembelajaran yang yang membuat siswa menjadi aktif tepat agar pembelajaran menjadi lebih dalam mengikuti pembelajaran aktif.

Berdasarkan permasalahan yang Rencana Anggaran Biaya salah satunya dengan menggunakan model sebelumnya telah diuraikan maka pembelajaran kooperatif. Menurut diperlukan upaya untuk mengoptimal- Asyirint (2010:61) beberapa tujuan kan proses pembelajaran dan hasil pembelajaran kooperatif adalah Untuk pembelajaran khususnya Kelas X A meningkatkan daya kemampuan siswa Teknik Gambar Bangunan SMK dalam menyelesaikan tugas-tugas Negeri 2 Sukoharjo tahun ajaran akademik, terutama melatih siswa 2016/2017. Salah satu upaya yaitu untuk memahami materi, dan melatih dengan menerapkan model siswa untuk mengembangkan pembelajaran kooperatif tipe Student ketrampilan sosial, keaktifan, bisa Teams Achievement Division (STAD) saling menghargai, dan bekerjasama melalui Lesson study. dalam satu team maupun dengan team

Menurut Prayekti dan Rasyimah lain. Ada beberapa macam pembelajarn (2012): Lesson study bukanlah suatu kooperatif salah satunya adalah Student strategi atau metode dalam Teams Achievement Division (STAD), pembelajaran, tetapi merupakan salah manfaat pembelajaran kooperatif tipe 
STAD menurut Linda Lundgren dan Nur dalam (Faiz: 2016) adalah meningkatkan kerja sama antar sesama anggota kelompok serta hasil belajar lebih tinggi. Slavin, R.E (1995:430) menyatakan bahwa "STAD is made up of five major components: class presentations, teams, quizzes, individual improvement scores, and team recognition". Pada pembelajaran kooperatif tipe STAD ada lima tahapan yang meliputi : 1) tahap penyajian materi, 2) tahap kegiatan kelompok, 3) tahap tes individual, 4) tahap perhitungan skor perkembangan individu, 5) tahap pemberian penghargaan kelompok.

Penelitian sebelumnya juga menyatakan bahwa dengan menggunakan metode pembelajaran kooperatif tipe Student Teams Achievement Division atau dengan menggunakan lesson study dapat meningkatkan keaktifan dan hasil belajar siswa, antara lain penelitian oleh: Sarisavinarinawatie Shahrani Leong, S. S. M., Said, H. M., Shahrill, M., \& Perera, J. S. H. (2016); Amornsinlaphachai, P. (2014); Lasi Negara, Suara (2014); Tran, V. D.
(2013); Tiantong, M., \& Teemuangsai, S. (2013); Tarim, K., \& Akdeniz, F. (2008).

Berkaitan dengan uraian masalah di atas, maka peneliti menggunakan model Pembelajaran Kooperatif Tipe Student Teams Achievement Division (STAD) melalui Lesson study untuk meningkatkan keaktifan siswa pada mata pelajaran rencana anggaran biaya Kelas X Teknik Gambar Bangunan SMK Negeri 2 Sukoharjo Tahun Pelajaran 2016/2017.

Berdasarkan masalah di atas, maka tujuan penelitian tindakan kelas ini adalah sebagai berikut : 1) Untuk mengetahui cara penerapan yang sesuai model pembelajaran kooperatif tipe Student Teams Achievement Division (STAD) melalui Lesson study untuk meningkatan keaktifan siswa dan hasil belajar siswa dalam pelajaran Rencana Anggaran Biaya pada siswa kelas X A Teknik Gambar Bangunan SMK Negeri 2 Sukoharjo. 2)Untuk mengetahui peningkatan keaktifan siswa dan hasil belajar siswa dalam pelajaran Rencana Anggaran Biaya pada siswa kelas X A Teknik Gambar Bangunan SMK Negeri 2 Sukoharjo 
melalui penerapan yang sesuai model pembelajaran kooperatif tipe Student Teams Achievement Division (STAD) melalui Lesson study

\section{METODE PENELITIAN}

Tempat penelitian tindakan kelas pada penelitian ini dilaksanakan di SMK Negeri 2 Sukoharjo. Teknik pengumpulan data yang digunakan yaitu dengan observasi yang dilakukan selama kegiatan pembelajaran mata pelajaran RAB berlangsung. Data observasi dituangkan dalam bentuk lembar observasi tertulis, wawancara dilakukan kepada guru dan siswa pada sebelum dan sesudah penelitian, data yang diambil adalah dokumentasi video, dan foto kegiatan pembelajaran mata pelajaran Rencana Anggaran Biaya sebelum dan sesudah dilaksanakan tindakan penelitian, daftar hasil tes, Silabus, RPP, dan Tes yang dilakukan untuk mengetahui kemampuan siswa dalam memahami mata pelanjaran $\mathrm{RAB}$ yaitu dengan tes tertulis berupa soal-soal yang harus dikerjakan.
Teknik validitas data yang digunakan dalam penelitian ini adalah teknik triangulasi. Pada penelitian tindakan kelas ini, teknik analisis yang digunakan oleh peneliti adalah interaktif kualitatif. Aktivitas dalam analisis data kualitatif dilakukan secara interaktif dan berlangsung secara terus menerus sampai tuntas. Aktivitas dalam analisis data, yaitu data reduction, data display, dan conclusion drawing/verification.

Pola dalam penelitikan tindakan kelas yaitu perencanaan, pelaksanaan dan pengamatan, refleksi, perencanaan ulang, tindakan baru dan observasi, refleksi lebih lanjut dan sebagainya. Rencana tindakan pada penelitian ini adalah sebagai berikut:

1) Tahap perencanaan melakukan analisis masalah terhadap kegiatan pembelajaran RAB berdasarkan hasil observasi pada prasiklus/pratindakan, berkolaborasi dengan guru dan tim observer Lesson Study melakukan Plan yaitu menentukan tindakan perencanaan yaitu dengan penerapan model pembelajaran kooperatif dengan metode Student Teams Achievement Division (STAD), menyusun 
jadwal pembelajaran yang disetujui oleh guru untuk pelakasanaan penelitian tindakan, menyusun instrumen penelitian yaitu berupa perangkat pembelajaran meliputi daftar kelompok, RPP, materi ajar, kisi-kisi lembar observasi, butir penilaian, soal diskusi, dan soal tes, mengkonsulkan hasil penyusunan perangkat pembelajaran dan hasil dari perencanaan/plan kepada guru yang bersangkutan.

2) Tahap pelaksanaan tindakan Guru menjelaskan kepada siswa prosedur pelaksanaan pembelajaran Student Teams Achievement Division (STAD), siswa dibagi ke dalam 7 kelompok masing-masing kelompok terdiri 4-5 anggota kelompok berdasarkan karakterisktik heterogen dengan jumlah siswa 34 siswa, guru membacakan nama kelompok masing-masing, siswa berkelompok, Guru menjelaskan materi, Guru membagikan tugas yang dibagikan kepada semua kelompok, Semua anggota kelompok mendiskusikan tugas yang diberikan oleh guru, Guru berkeliling setiap kelompok atau siswa untuk memeriksa dan membantu siswa, Guru mengkondisikan siswa ke posisi semula, Guru memberikan soal tes individu untuk mengetahui kemampuan siswa menerima pelajaran, Guru memberikan kesimpulan.

3) Observasi, pada tahap ini dilakukan observasi terhadap pelaksanaan tindakan berlangsung. Observasi ini dilakukan oleh tim observer lesson study yaitu dengan mengamati aktivitas siswa dalam pembelajaran rencana anggaran biaya dari awal pembelajaran sampai aktivitas siswa sesuai dengan apa yang tercantum dalam lembar observasi atau tidak, atau sesuai tidak dengan kriteria keberhasilan yang telah dibahas pada tahap perencanaan/plan.

4) Refleksi, pada tahap ini peneliti mengecek kelengkapan data pengumpulan data yang terjaring selama proses tindakan, melakukan perhitungan skor perkembangan individu siswa dan predikat kelomopok STAD (penghargaan), mendiskusikan dan pengumpulan data antara guru, peneliti, dan observer lesson study berupa hasil belajar siswa, hasil pengamatan, catatan lapangan, dan lain-lain dilakukan pada saat tahap pelaksanaan/do. 
Penyusunan rencana tindakan berupa penerapan metode berikutnya yang dirumuskan dalam pembelajaran STAD (pratindakan), skenario pembelajaran dengan berdasar sampai dengan setelah diberi tindakan pada analisa data dari proses tindakan berupa penerapan metode pembelajaran sebelumnya untuk memperbaiki proses STAD (siklus I, siklus II, siklus III). pembelajaran yang telah dilakukan Dari hasil penelitian dapat dilihat pada siklus sebelumnya untuk bahwa penerapan metode pembelajaran menyusun tindakan yang akan Student Teams Achievement Division dilakukan pada siklus berikutnya. (STAD) keaktifan siswa dan hasil belajar siswa mengalami peningkatan

\section{HASIL TINDAKAN DAN PEMBAHASAN}

Hasil tindakan antar siklus ini setiap siklusnya. Peningkatan setiap indikator dalam penelitian dapat disajikan sebagai berikut: dimulai dari sebelum diberi tindakan

Tabel 1. Peningkatan hasil penelitian

\begin{tabular}{|c|c|c|c|c|c|c|}
\hline \multirow[b]{2}{*}{ No. } & \multirow[b]{2}{*}{ Aspek yang Diukur } & \multirow{2}{*}{$\begin{array}{c}\text { Presentase } \\
\text { Target } \\
\text { Capaian }\end{array}$} & \multicolumn{4}{|c|}{ Prosentase } \\
\hline & & & Pratindakan & $\begin{array}{l}\text { Siklus } \\
\text { I }\end{array}$ & $\begin{array}{l}\text { Siklus } \\
\text { II }\end{array}$ & $\begin{array}{c}\text { Siklus } \\
\text { III }\end{array}$ \\
\hline 1. & Keaktifan & $78 \%$ & $6,25 \%$ & $38,24 \%$ & $67,65 \%$ & $91,18 \%$ \\
\hline 2. & $\begin{array}{l}\text { Hasil belajar ranah } \\
\text { kognitif }\end{array}$ & $78 \%$ & $40,625 \%$ & $52,94 \%$ & $67,65 \%$ & $91,18 \%$ \\
\hline 3. & $\begin{array}{l}\text { Hasil belajar ranah } \\
\text { afektif }\end{array}$ & $78 \%$ & $53,125 \%$ & $79,41 \%$ & $88,24 \%$ & $94,12 \%$ \\
\hline 4. & $\begin{array}{l}\text { Hasil belajar ranah } \\
\text { psikomotorik }\end{array}$ & $78 \%$ & $46,875 \%$ & $50 \%$ & $55,88 \%$ & $82,35 \%$ \\
\hline
\end{tabular}

Berdasarkan tabel 1, terlihat data yang peningkatan. Keberhasilan pelaksanaan disajikan dari pratindakan sampai penerapan model pembelajaran dengan siklus III mengalami kooperatif tipe Student Teams 
Achievement Division (STAD) analisis data penilaian melalui berdampak pada peningkatan keaktifan observasi rata-rata siswa masih kurang belajar siswa, dan dengan dalam sikap toleran dan kejujuran, meningkatnya keaktifan belajar siswa karna pada asaat pembelajaran maka hasil belajar siswa juga berlangsung sebagian siswa masih meningkat.

Berdasarkan hasil analisis data observasi yang dilakukan selama pratindakan, keaktifan siswa pada saat pembelajaran berlangsung, siswa masih kurang. Sebagian besar siswa pada saat guru menerangkan hanya mendengarkan saja, beberapa siswa mau mencatat, namun sebagian lainnya ada yang mengobrol dengan teman, dan ada yang mengantuk. Saat guru memberikan kesempatan bertanya atau pada saat guru memberi pertanyaan hanya beberapa siswa saja yang mau bertanya atau menjawab pertanyaan dari guru.

Hasil belajar siswa pada pratindakan untuk ranah kognitif didapatkan dari hasil tes tertulis yang diberikan pada akhir pembelajaran pada saat pratindakan. Sedangkan ranah Afektif, nilai didapatkan berdasarkan hasil observasi peneliti dan observer dengan lembar observasi ranah afektif. Berdasarkan hasil mengobrol pada saat ada teman yang bertanya pada guru maupun pada saat guru menerangkan sedangkan pada saat mengerjakan tes tertulis sebagian siswa masih terlihat belum percaya diri dan menjawab tes dengan tidak teliti. Ketelitian siswa dalam menjawab tes tertulis masih kurang, sehingga hasil belajar ranah psikomotorik maish kurang.

Untuk menumbuhkan keaktifan, dan hasil belajar siswa maka diperlukan metode pembelajaran baru agar pembelajaran di kelas menjadi lebih menarik, untuk mengatasi masalah tersebut dipilih model pembelajaran kooperatif tipe Student Teams Achievemment Division (STAD).

$$
\text { Pelaksanaan siklus I }
$$
direncanakan oleh peneliti, tim observer lesson study dan guru pengampu mata pelajaran rencana anggaran biaya. Pada saat pembelajaran tim observer lesson study 
mengamati keaktifan siswa dan saat berdiskusi kelompok. Sedangkan aktifitas belajar siswa. Keaktifan siswa pada ranah psikomotorik (ketrampilan) mengalami peningkatan dari masih sama dengan pratindakan hanya pratindakan, terlihat siswa mencatat materinya saja yang berbeda. Ketelitian materi yang disampaikan oleh guru dan siswa dalam menjawab pada siklus ini saat guru memberikan soal untuk salah satu siswa mencoba mengerjakan ke depan kelas siswa tersebut mau mengerjakan. Sebelum dilakukan diskusi kelompok, anggota kelompok dibagi secara heterogen, jumlah kelompok yaitu 7 kelompok yang masing-masing kelompok terdiri dari 45 anggota kelompok. Selama diskusi kelompok terlihat keaktifan siswa saling membantu pada saat mengerjakan soal diskusi dan apabila mengalami kesulitan siswa tidak ragu untuk bertanya kepada guru. terlihat juga masih kurang, hasil dari ranah psikomotorik juga meningkat dari siklus senbelumnya.

Pelaksanaan siklus II direncanakan oleh peneliti, tim observer lesson study dan guru pengampu mata pelajaran rencana anggaran biaya. Keaktifan siswa pada siklus II juga mengalami peningkatan dibandingkan dengan siklus I. Pada siklus II mengalami peninggkatan. Peningkatan ini dapat dilihat saat pemebalajarn dimulai guru Berdasarkan hasil pengamatan yang dilakukan peneliti dan observer lesson study keaktifan belajar siswa mengalami peningkatan dari pratindakan sebelumnya.

Hasil belajar ranah kognitif siswa mengalami peningkatan dari siklus sebelumnyaNilai ranah afektif pada siklus I mengalami peningkatan. Sikap toleransi siswa pada siklus I siswa sudah mulai meningkat baik pada memberikan contoh kurva $\mathrm{S}$ bangunan 7 lantai, siswa diberi kesempatan untuk menganalisis, setelah menganalisis dan mengamati kurva S bangunan 7 lantai beberapa siswa bertanya kepada guru. Karena siswa sudah mulai terbiasa berdiskusi siswa mulai mempunyai rasa tanggung jawab dalam kelompoknya, siswa terihat lebih aktif ikut memberikan pendapat dalam kelompok dan bertanya apabila masih belum paham. saat guru menerangkan, maupun pada 
Hasil belajar pada siklus II belum aktif pada siklus sebelumnya terlihat mengalami peningkatan juga pada siklus III menunjukkan dibandingkan dengan siklus I. Pada peningkatan dengan memberikan siklus II hasil belajar ranah kognitif pendapat dan ikut mengerjakan soal walaupun materi yang disampaikan diskusi kelompok. Siswa yang belum sama namun sebagian siswa masih paham juga tidak ragu untuk bertanya kurang teliti dalam membuat grafik kepada guru sehingga pembelajaran kurva $\mathrm{S}$ dan kurang teliti pada saat menjadiaktif. mengerjakan time schedule.

Hasil belajar siklus III ranah

Hasil belajar ranah afektif kognitif ,afektif dan psikomotorik siklus II sudah mengalami peningkatan. Namun siswa yang mendapat predikat Kurang (K) masih ada 4 siswa hal tersebut karena siswa-siswa tersebut masih kurang dalam nilai kejujuran, kerjasama dalam kelompok, dan disiplin masih kurang. Nilai ranah psikomotorik mengalamai peningkatan, ketelitian siswa dalam mengerjakan sangat mempengaruhi nilai psikomotorik siswa.

Siklus III dimulai dari tahap perencanaan/plan melibatkan guru secara langsung sehingga tahap plan lebih matang, selain dengan guru plan dihadiri oleh tim observer lesson study. Keaktifan siswa juga mengalami peningkatan pada saat diskusi siswa sudah mulai terbiasa dengan keadaan diskusi sehingga kondisi kelas lebih kondusif untuk berdiskusi. Siswa yang mengalami peningkatan yang cukup banyak Dapat disimpulkan bahwa mengalami peningkatan yang cukup baik dari siklus sebelumnya, hal ini karena siswa nilai kejujuran, kerjasama dan toleransi siswa meningkat dari siklus sebelumnya. Selain itu siswa sudah mengadaptasikan langkahlangkah perhitungan yang disampaikan guru dengan baik, serta sudah banyak siswa yang menyediakan alat hitung dan mengoprasikannya dengan baik/sesuai dengan fungsinya.

Hasil belajar siswa dalam ranah afektif, kognitif dan psikomotorik meningkat pada setiap siklusnya. Hasil tersebut sejalan dengan pendapat Linda Lundgren dan Nur bahwa keuntungan pembelajaran kooperatif tipe STAD adalah hasil belajar lebih tinggi. Dalam 
pembelajaran rencana anggaran biaya dengan model pembelajaran kooperatif tipe STAD dapat dikatakan sukses karena dalam pembelajaran tersebut memunculkan keaktifan siswa, selama pembelajaran berlangsung mulai dari siklus I sampai dengan siklus III setiap siklusnya mengalami penigkatan keaktifan. Sesuai dengan pendapat Alferd Alder yag dikutip dalam Warsono \& Hariyanto (2012: 4) menjelaskan belajar yang sukses adalah belajar yang memunculkan keaktifan bukan pasif. Keaktifan adalah sebuah proses yang dimulai dan didominasi oleh siswa, bukan guru.

Berdasarkan hasil wawancara dengan guru pengampu pelajaran rencana anggaran biaya dengan adanya lesson study guru mendapatkan manfaat yaitu bisa menyusun perencanaan pembelajaran secara kolaborasi dengan tim lesson study. Menurut pendapat siswa dalam wawancara menyampaikan bahwa dengan adanya model pembelajaran kooperatif tipe Student Teams Achievement Division (STAD) siswa merasa lebih paham dengan pembelajaran karena bisa bekerjasama dengan temannya, atau bisa bertanya dengan temannya, dan merasa pembelajaran lebih menyenangkan, dan teman yang biasanya diam saja berani bertanya baik dengan teman maupun dengan guru. Dalam wawancara siswa ada siswa yang menyampaikan juga bahwa dengan adanya observer lesson study siswa tersebut merasa kurang nyaman karena merasa diawasi, namun ada juga siswa yang menyampaikan bahwa dengan adanya observer lesson study siswa tersebut merasa biasa saja dan tidak terganggu.

Hasil penerapan model pembelajaran kooperatif tipe Student Teams Achievement Division (STAD) melalui Lesson study pada kelas X TGB A SMK Negeri 2 Sukoharjo terbukti dapat meningkatkan keaktifan dan hasil belajar siswa. Ranah kognitif, ranah afektif dan ranah psikomotorik dari pratindakan sampai Siklus III mengalami peningkatan nilai ketuntasan. Hal ini sejalan dengan beberapa peneliti sebelumnya. Lasia, Negara, Suara (2014) dalam penelitiannya menyimpulkan bahwa penerapan kooperatif tipe STAD dapat meningkatkan keaktifan dan hasil belajar siswa dalam mata pelajaran IPS di kelas III SD Negeri 12 Padang 
Sambian. Prayekti dan Rasyimah (2012) menyimpulkan bahwa setelah dilakukan lesson study hasil yang diperoleh siswa, selain terlibat langsung dalam proses pembelajaran, kreativitas lebih meningkat baik dalam kegiatan diskusi maupun melaksanakan percobaan IPA dengan pertanyaanpertanyaan yang diajukan terkait dengan materi yang dibahas. Dalam kegiatan diskusi kelompok nampak siswa-siswa yang lebih menonjol dari teman-teman satu kelompoknya, sehingga pembelajaran IPA menjadi hidup dan kegiatan lebih terpusat pada siswa, dan lebih berkembang.

\section{SIMPULAN}

Penerapan model pembelajaran kooperatif tipe Student Teams Achievement Division (STAD) melalui Lesson study dimulai dari tahap perencanaan (plan), tahap pelaksanaan (do) diterapkan model pembelajaran kooperatif tipe Student Teams Achievement Division (STAD), tahap observasi, dan tahap yang terakhir yaitu tahap refleksi (see). Berdasarkan hasil analisis data penelitian menunjukkan Model pembelajaran kooperatif tipe Student Teams Achievement Division
(STAD) melalui Lesson study dpat meningkatkan keaktifan dan hasil belajar siswa.

\section{DAFTAR PUSTAKA}

Amornsinlaphachai, P. (2014). Designing a learning model using the STAD technique with a suggestion system to decrease learners' weakness. Procedia-Social and Behavioral Sciences, 116, 431-435.

Asyirint, G. (2010). Langkah Cerdas Menjadi Guru Sejati Berprestasi. Yogyakarta: Bahtera Buku.

Faiz, A. (2016). Pengertian Persiapan Langkah dan Kelebihan serta Kekurangan Pembelajaran Kooperatif Tipe STAD. Diperoleh 26 Desember 2016, dari

http://www.wawasanpendidik an.com/2016/01/Pengertian-

Persiapan-Langkah-danKelebihan-serta-KekuranganPembelajaran-KooperatifTipe-STAD/

Lasia, I. N., Negara, I. G. A. O., Ke, S. P. M., \& Suara, I. M. (2014). Penerapan Pendekatan Kooperatif Tipe STAD Untuk Meningkatkan Keaktifan dan 
Hasil Belajar Siswa dalam Mata Pelajaran IPS di Kelas III SD Negeri 12 Padang Sambian Kota Denpasar Tahun 2013/2014. Jurnal MIMBAR PGSD, 2(1). Diperoleh pada 20 Desember 2016, dari http://ejournal.undiksha.ac.id/i ndex.php/JJPGSD/article/view 12302

Leong, S. S. M., Said, H. M., Shahrill, M., \& Perera, J. S. H. (2016). Using lesson study to enhance meaningful understanding on the topic of pressure. International Journal of Environmental and Science Education, 11 (15), 84258435. Diperoleh pada 26 April 2017 , dari https://www.researchgate.net/ profile/Masitah_Shahrill/publi cation/308889245_Using_Les son_Study_to_Enhance_Mean ingful_Understanding_on_the _Topic_of_Pressure/links/57f4 f11c08ae280dd0b8c6d8.pdf

Prayekti \& Rasmiyah, (2012). Lesson study untuk Meningkatkan Hasil Belajar Ilmu Pengetahuan Alam Bagi Siswa Sekolah Dasar. Jurnal Pendidikan dan Kebudayaan, 18 (1) 54-64.

Slavin, R. E. (1995). Student teamsachievement divisions in the secondary classroom.

Secondary schools and cooperative learning: Theories, models, and strategies, 425-446.

Tarim, K., \& Akdeniz, F. (2008). The effects of cooperative learning on Turkish elementary students' mathematics achievement and attitude towards mathematics using TAI and STAD methods. Educational studies in Mathematics, 67(1), 77-91.

Tiantong, M., \& Teemuangsai, S. (2013). Student Team Achievement Divisions (STAD) Technique Through The Moodle To Enhance Learning Achievement. International Education Studies, 6(4), 85.

Tran, V. D. (2013). Effects Of Student Teams Achievement Division (STAD) On Academic Achievement, And Attitudes of Grade 9th Secondary School Students Towards Mathematics. International Journal of Sciences, 2(201304), 5-15.

Warsono \& Haryanto (2012). Pembelajaran Aktif Teori dan Assesmen. Bandung: PT. Remaja Rosdakarya. 